\title{
Spring and fall microheterotrophic utilization of dissolved free amino acids in a California Borderland basin
}

\author{
D. B. Craven ${ }^{1}$, A. F. Carlucci ${ }^{2}$ \\ ${ }^{1}$ Skidaway Institute of Oceanography, PO Box 13687, Savannah, Georgia 31416, USA \\ ${ }^{2}$ Institute of Marine Resources, A-018 Scripps Institution of Oceanography, University of California, San Diego, La Jolla, \\ California 92093, USA
}

\begin{abstract}
Seasonal variation in microheterotrophic utilization of dissolved free amino acids (DFAA) was examined in depth profiles from the central Santa Monica Basin, a California Borderland basin offshore of Los Angeles. Although little change was observed between spring and fall in bacterial abundances, DFAA concentrations, or utilization in the basin midwaters, a substantial increase was measured in all parameters under late spring bloom conditions in euphotic zone waters and in fall in the benthic boundary layer (BBL). Neither zone showed enhanced values in early spring. Late spring euphotic zone bacterial abundances, total dissolved free amino acids (TFAA) and utilization of selected DFAA increased 2 to 4 -fold over fall values, while values in the BBL increased by similar ratios over those measured in spring. Benthic utilization of spring bloom detritus apparently continued into the fall season in the basin environment studied. Utilization of a single DFAA, glutamic acid, and of a mixture of glutamic acid, aspartic acid and serine were highly correlated throughout the water column in spring and fall, although TFAA utilization rates calculated using glutamic acid alone slightly overestimated rates using the mixture. DFAA utilization was estimated to account for a larger fraction of primary carbon production in fall (11 to $18 \%)$ than in early $(1 \%)$ or late spring $(7 \%)$.
\end{abstract}

\section{INTRODUCTION}

Although primary carbon production and secondary heterotrophic processes are regarded as tightly-coupled phenomena in aquatic systems (Pomeroy 1974, Cole et al. 1988), current models suggest that primary production can be uncoupled from heterotrophy, particularly from grazing, when bloom conditions exist in the euphotic zone (Frost 1987). Phytoplankton exudation can constitute a significant portion of total fixed carbon (see Fogg 1983, Bjornsen 1988 and references therein), and may be readily utilized by microheterotrophs within the euphotic zone. Major labile constituents of such exudates are dissolved free and combined amino acids (DFAA and DCAA; Thomas 1971, Mague et al. 1980, Keller et al. 1982) and carbohydrates (Burney et al. 1982). Proteolytic activity maxima associated with the bacteria-size fraction have been reported within chlorophyll maxima (Rosso \& Azam 1987). Diel and seasonal variation in exudation and associated microheterotrophic processes are well-documented (Jørgen- sen 1982, Carlucci et al. 1984 and references therein, Rosso \& Azam 1987).

While earlier studies indicated that a principal component of vertical flux out of the euphotic zone is zooplankton fecal pellets (Urrere \& Knauer 1981, Ittekot et al. 1984a, b), more recent evidence shows that minimally-altered phytoplankton aggregates may also undergo rapid transport to the seafloor, given episodic euphotic zone bloom conditions of a magnitude sufficient to overwhelm grazing control (Billett et al. 1983, Lampitt 1985). Phytodetritus was observed on the seafloor following spring blooms at a site in the North Atlantic, at time intervals necessitating water column transits of a minimum of $100 \mathrm{~m} \mathrm{~d}^{-1}$. Although initially few fecal pellets were observed in addition to the phytodetritus, such evidence of zooplankton feeding began to appear as the euphotic zone bloom progressed. Enhanced seasonal benthic heterotrophy following the spring bloom has also been documented for the North Pacific (Smith \& Baldwin 1984, Smith 1987). Whatever mechanism is invoked, it is apparent 
that the benthos is more sensitive to seasonal fluctuation than had been originally speculated.

Most fixed carbon which escapes the euphotic zone as phytodetritus or fecal pellets descends rapidly to the bottom through depauperate midwaters where microbiological decomposition processes are regarded as minimal. Recent reports suggest that such large particles are not likely sites for microbial degradation of organic carbon in transit (Karl et al. 1988), and that most microbial activity in midwaters occurs in association with a smaller, suspended-particle size class that includes bacteria (Cho \& Azam 1988, Karl et al. 1988). An exception to this scenario is the midwaters in oxygen minimum zones, where microbial rate processes can be dramatically enhanced (Codispoti et al. 1986). One recent model divides oceanic midwaters into an upper zone of active particle recycling and a deeper zone of passive particle transit where particles which escape the upper waters survive to the seafloor (Jahnke \& Jackson 1987).

The benthic boundary layer (BBL) extends from the top of the nepheloid layer to within the top several $\mathrm{cm}$ of sediment. It is a transitional zone resulting from vertical and lateral transport processes and resuspension from sediments. Increases in microbial and macrofaunal abundances and activity, and in dissolved and articulate constituents, have been reported compared to midwaters. The benthos and $\mathrm{BBL}$ population are actively involved in dissolution of particulate organic carbon (POC) to dissolved organic carbon (DOC), and subsequent decomposition and remineralization of the transported carbon. Microheterotrophs, predominantly bacteria, have been demonstrated to play a dominant role in such processes (Smith et al. 1986, 1987). Proteolytic activity has been shown to be dramatically higher in surface sediments than in overlying waters (Rosso \& Azam 1987).

A recent study of central Pacific waters concluded that the most labile DOC fractions are DFAA, DCAA and dissolved carbohydrates, and estimated that these components account for ca 6 and $16 \%$ of DOC in deep and shallow waters, respectively (Williams \& Druffel 1987), although the percentages given may be overestimated since determination of DOC values by wet oxidation has been criticized (see Williams \& Druffel 1988 for a discussion). One recent review of North and Baltic Sea bacterial ecology indicated that mean carbon utilization rates were quite similar for aspartate, acetate and glucose (coefficients of variation $23 \%$ and $52 \%$ for the 2 stations presented; Rheinheimer 1984). It has also been suggested that the low-nutrient conditions typical of most of the world oceans require metabolic adaptations toward high substrate affinity and relatively low substrate specificity for marine bacteria (Poindexter 1981, Carlucci et al. 1987). Consequently, while the use of DFAA as tracers for total DOC cycling is unrealistic, DFAA utilization and turnover may be representative of the activity of the biologically labile DOC pool. Measurement of DFAA utilization processes can be a convenient indicator of relative activity within the labile pool and may be used to indicate spatial and temporal patterns in labile DOC utilization.

We here present depth distributions and apparent seasonal variation in bacterial abundances and DFAA concentrations and utilization rates in a southern California marine basin environment. We also compare utilization of an individual DFAA with a mixture of 3 DFAAs that are ubiquitous in the waters studied.

\section{MATERIALS AND METHODS}

Sampling. Santa Monica Basin is a nearshore basin located southwest of Los Angeles, California, in the NW-SE trending series of basins and ridges referred to as the California Continental Borderland. The station is located in the central basin $\left(33^{\circ} 45.5^{\prime} \mathrm{N}\right.$, $118^{\circ} 48.1^{\prime} \mathrm{W}$ ) at maximum basin depth of ca $908 \mathrm{~m}$. Water column profiles were studied during 4 cruises to the Santa Monica Basin aboard the RV 'New Horizon'. Samples were collected at 8 depths in October (fall) 1985. May (late spring) and October (fall) 1986 and April (early spring) 1987. Euphotic zone waters were collected in the early to mid afternoon, when microheterotrophic DFAA utilization is maximal in the study area (Carlucci et al. 1984). Samples were retrieved with a 5 l Niskin bottle which was washed, initially and between sample depths, sequentially with $10 \% \mathrm{HCl}_{1}$ Corning-distilled water and absolute methanol. Plastic gloves were worn during all sample handling to eliminate potential sources of contamination. Subsamples were drawn into baked $\left(500^{\circ} \mathrm{C}\right)$ glass prescription bottles with acid-cleaned, Teflonlined caps and stored on ice until use, always less than $1 \mathrm{~h}$ and typically less than $15 \mathrm{~min}$.

Three $40 \mathrm{ml}$ replicates and one control (5\% formalin, final concentration) were incubated for each substrate used at each depth sampled. After dispensing aliquots into baked Pyrex tubes, each sample received ca $1 \mu \mathrm{Ci}$ of either $\left[3,4-{ }^{3} \mathrm{H}\right]$-glutamic acid (ICN, $50 \mathrm{Ci} \mathrm{mmol}^{-1}$, final concentration $0.3 \mathrm{n} M$ for October 1985 and May 1986, $0.5 \mathrm{n} M$ for all other times) or a mixture of glutamic acid (as above), $\left[2,3-{ }^{3} \mathrm{H}\right.$-aspartic acid (ICN. $20 \mathrm{Ci} \mathrm{mmol}{ }^{-1}$ ) and $\left[\mathrm{G},{ }^{3} \mathrm{H}\right]$-serine (ICN, $8 \mathrm{Ci} \mathrm{mmol}^{-1}$ ), for May and October 1986 only. The mixture used for May was 1.3:1:1 molar ratio of glutamic acid:aspartic acid:serine, $0.9 \mathrm{n} M$ final concentration addition, based on ambient ratios determined previously in Santa Monica and adjacent San Pedro Basins. The ratio was altered for October to $1: 1.5: 3$ (1.1 $\mathrm{n} M$, final concen- 
tration), based on DFAA determinations made on the May 1986 samples.

Incubations were performed in the dark aboard ship at in situ temperature $\left( \pm 1 \mathrm{C}^{\circ}\right)$ for 1 to $6 \mathrm{~h}$, depending on the depth of sample origin and expected microbial activity. All incubations were at 1 atm hydrostatic pressure. The effects of hydrostatic pressure on microbial activities are minimal between surface waters and $2000 \mathrm{~m}$ depth (see Carlucci et al. 1986 for discussion). Samples were filtered through Millipore $\mathrm{PH}$ filters (0.3 $\mathrm{um}$ pore size, $25 \mathrm{~mm}$ diameter) following incubation; filter edges were carefully rinsed with filtered seawater and the filtered particulates were counted in glass scintillation vials containing $8 \mathrm{ml}$ Ecoscint (National Diagnostics), using external standard ratios to correct for quenching in a Beckman LS $100 \mathrm{C}$ scintillation counter. Filtrate aliquots were collected and frozen for subsequent determination of ${ }^{3} \mathrm{H}_{2} \mathrm{O}$ production as described elsewhere (Carlucci et al. 1984). Mean coefficients of variation for triplicates at 8 depths ranged from $9.6 \%$ (October 1985) to $29.1 \%$ (October 1986).

Additional water from each depth was formalin-preserved ( $5 \%$ final concentration) to determine bacterial abundances via acridine orange epifluorescence microscopy. Methods differed from those used previously (Carlucci et al. 1984) in that acridine orange-stained samples were not rinsed with distilled water following filtration, as rinsing was found to increase the heterogeneous distribution of cells on the filters. Triplicate subsamples were counted for each depth, with a minimum count of 20 fields or 300 cells for each subsample. Mean coefficients of variation for triplicate determinations at 8 depths were 7.0 to $12.4 \%$ for all profiles.

Waters collected for determination of DFAA were filtered in a baked $\left(500^{\circ} \mathrm{C}\right)$ glass filtration rig through precleaned $0.22 \mathrm{um}$ Nuclepore filters and frozen immediately. Samples were returned to the shorebased laboratory for subsequent DFAA analysis via HPLC methods (Henrichs \& Williams 1985) with an acetonitrile-acetate buffer solvent system. Samples were derivatized with $o$-phthaldialdehyde and the reaction was quenched with acetic acid immediately prior to column injection (Robertson et al. 1987). When replicate subsamples were run to check precision, differences were $<10 \%$.

\section{RESULTS AND DISCUSSION}

The effect of the spring phytoplankton bloom in the euphotic zone is evident in both bacterial numbers (Fig. 1) and TFAA concentrations (Fig. 2) in May 1986, but the April 1987 study was apparently carried out too early in the season to sample any bloom, as euphotic zone values did not differ greatly between April and the 2 October studies. Note the difference in axes between seasons. Midwater distributions were similar

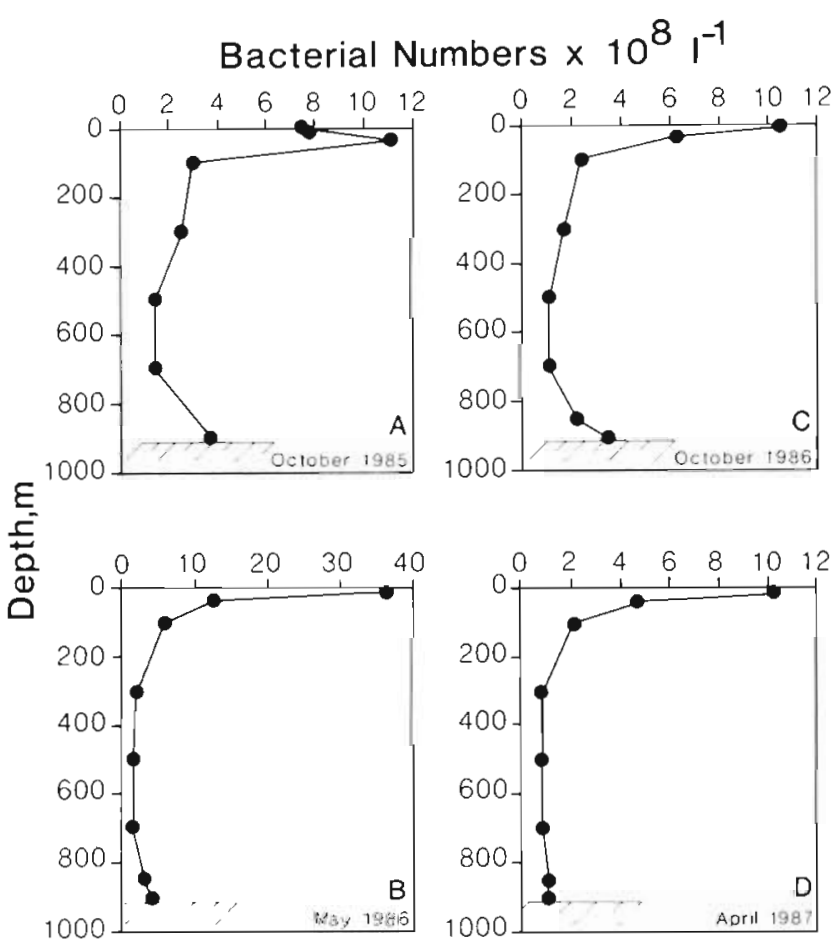

Fig. 1 Bacterial number distributions in the central Santa Monica Basin in (A) fall 1985, (B) late spring and (C) fall 1986. and (D) early spring 1987

TFAA, nM

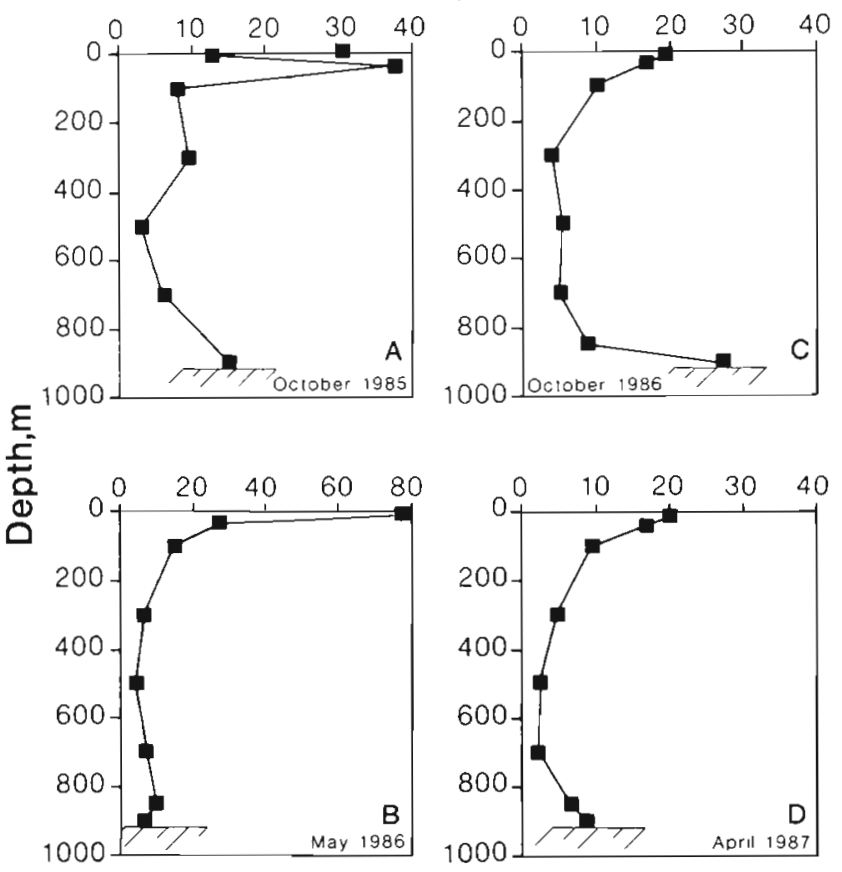

Fig. 2. Total dissolved free amino acid (TFAA) distributions in the central Santa Monica Basin in (A) fall 1985, (B) late spring and (C) fall 1986, and (D) early spring 1987 
Table 1. Depth-weighted mean bacterial abundances, TFAA concentrations, microheterotrophic glutamic acid, utilization and specific utilization rates in the central Santa Monica Basin. 'Bottom only' is deepest sample, 3 to $6 \mathrm{~m}$ from sediment

\begin{tabular}{|c|c|c|c|c|}
\hline Depth $(\mathrm{m})$ & Oct 85 & May 86 & Oct 86 & Apr 87 \\
\hline \multicolumn{5}{|c|}{ Bacterial abundance $\left(\times 10^{11} \mathrm{~m}^{-3}\right)$} \\
\hline 0-bottom & 2.84 & 3.99 & 2.14 & 1.51 \\
\hline $0-100$ & 7.91 & 15.80 & 6.03 & 5.31 \\
\hline $100-700$ & 2.07 & 2.39 & 1.54 & 1.06 \\
\hline 700 -bottom & 2.62 & 2.70 & 2.00 & 1.01 \\
\hline Bottom only & 3.72 & 4.20 & 3.50 & 1.13 \\
\hline \multicolumn{5}{|c|}{ Total free amino acids $\left(\mu \mathrm{mol} \mathrm{m} \mathrm{m}^{-3}\right)$} \\
\hline 0-bottom & 9.5 & 10.4 & 7.7 & 5.8 \\
\hline $0-100$ & 23.6 & 34.6 & 15.3 & 15.4 \\
\hline $100-700$ & 6.7 & 7.1 & 5.6 & 4.4 \\
\hline 700 -bottom & 10.8 & 8.4 & 10.1 & 5.3 \\
\hline Bottom only & 15.1 & 6.8 & 27.3 & 8.6 \\
\hline \multicolumn{5}{|c|}{ Glutamic acid utilization ( $\mathrm{nmol} \mathrm{m}^{-3} \mathrm{~h}^{-1}$ ) } \\
\hline 0-bottom & 28.2 & 43.0 & 15.5 & 4.9 \\
\hline $0-100$ & 154.0 & 294.2 & 82.2 & 34.4 \\
\hline $100-700$ & 7.6 & 14.2 & 6.7 & 1.5 \\
\hline 700-bottom & 27.3 & 5.2 & 8.6 & 0.8 \\
\hline Bottom only & 49.4 & 9.7 & 27.8 & 1.2 \\
\hline \multicolumn{5}{|c|}{ Specific utilization $\left(\mathrm{mol} \times 10^{-20} \mathrm{cell}^{-1}\right)$} \\
\hline 0 -bottom & 9.93 & 10.87 & 7.24 & 3.25 \\
\hline $0-100$ & 19.47 & 18.62 & 13.63 & 6.48 \\
\hline $100-700$ & 3.67 & 5.94 & 4.35 & 1.42 \\
\hline 700-bottom & 10.42 & 1.93 & 4.30 & 0.79 \\
\hline Bottom only & 13.28 & 2.31 & 7.94 & 1.15 \\
\hline
\end{tabular}

and relatively constant for bacterial abundances and TFAA at all times studied, but April 1987 values were always lowest. Although no consistent differences in bacterial numbers were observable between seasons in the near-bottom samples, a pronounced BBL increase was apparent in TFAA concentrations in both fall studies compared to early or late spring.

Full column integrated bacterial abundances were highest in late spring 1986, with a large euphotic zone concentration (Table 1). Abundances in the 2 fall studies were similar, while those in early spring 1987 were moderately to substantially lower at all depths compared to the previous 3 studies. The per-volume benthic bacterial abundance increased relative to euphotic zone values in fall (benthic ca $53 \%$ of euphotic) compared to spring (ca 24 nis).

Depth-weighted mean TFAA concentrations (Table 1) suggest only minor differences between May 1986 and October 1985, but integrations for the intervals 0 to $100 \mathrm{~m}, 100$ to $700 \mathrm{~m}$ and 700 to bottom (for descriptive purposes, 'euphotic', 'midwater' and 'deep' or 'benthic', respectively) show that the May TFAA value was dominated by the euphotic zone on a per volume basis, while October included an additional benthic increase. Although the full-column TFAA concentration was lower in October 1986 than October 1985, an even

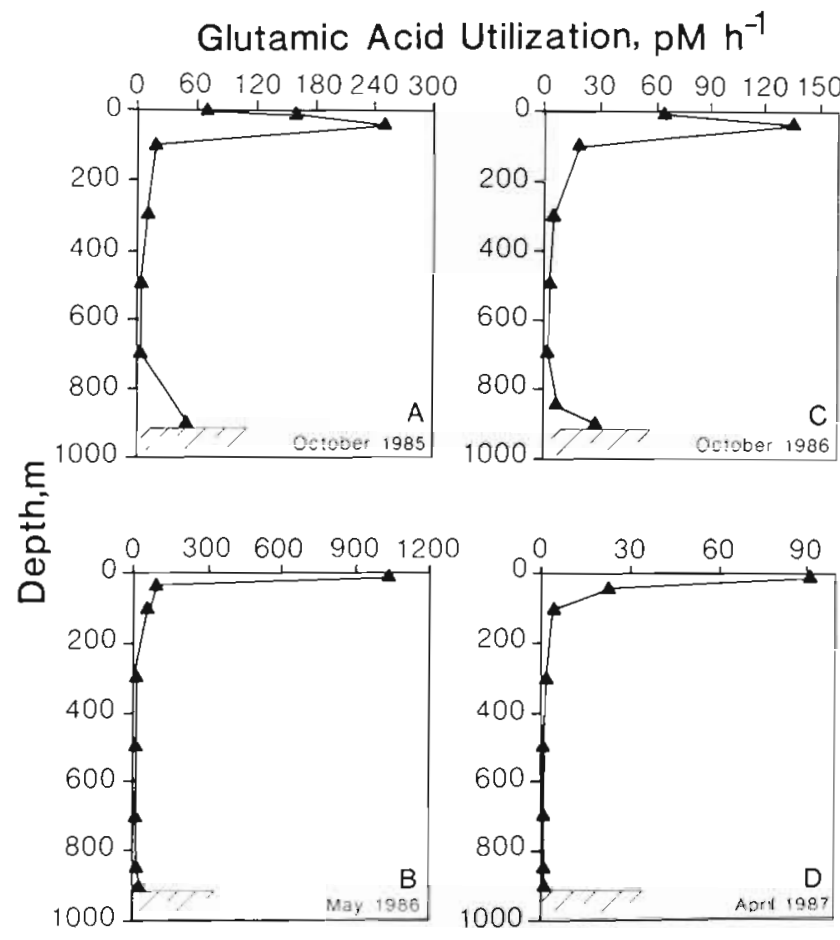

Fig. 3. Glutamic acid utilization rates in depth profiles in the central Santa Monica Basin in (A) fall 1985, (B) late spring and (C) fall 1986, and (D) early spring 1987

larger benthic concentration was evident. April 1987 showed neither enhancement to the same extent.

Glutamic acid utilization rates (Fig. 3; Table 1) in euphotic waters were highest in May 1986, while substantial benthic increases were observed in both October studies. October profiles were not significantly different ( $p>0.20$; Mann-Whitney $U$ test). Rates measured in April 1987 were lower throughout the water column than for any other time studied. April 1987 and May 1986 utilization profiles were significantly different ( $p<0.001$; Mann-Whitney $U$ test). Integrated utilization (Table 1) in October 1985 was about $66 \%$ of that measured in May, but the boundary layer component had increased dramatically while the euphotic zone component had decreased accordingly. October 1986 integrated utilization was lower than the previous fall measurement, but the boundary layer increase over that measured in May was again notable. April 1987 integrated utilization was the lowest measured at all depths studied, although the ratio of euphotic zone to deep water utilization rates is similar for April and May (ca 30:1) compared to October (ca 3:1). Calculation of depth-weighted mean specific utilization rates (in mol $\times 10^{-20}$ cell $\left.^{-1} h^{-1}\right)$, which assumes that all bacterial cells are active and that only bacteria utilize DFAAs, indicates that while euphotic zone bacterial populations were the most active on a per cell basis for all times studied, in the fall a distinct increase in activity 
Table 2. Comparison of mole percent, microheterotrophic utilization and calculated TFAA utilization for glutamic acid and mixture (glutamic acid, aspartic acid, serine) in May and October 1986

\begin{tabular}{|c|c|c|c|c|c|c|c|}
\hline \multirow{3}{*}{$\begin{array}{l}\text { Depth } \\
(\mathrm{m})\end{array}$} & \multirow{3}{*}{$\begin{array}{l}\text { TFAA } \\
(n M)\end{array}$} & \multirow{2}{*}{\multicolumn{2}{|c|}{$\begin{array}{c}\text { TFAA } \\
\text { (mole percent) }\end{array}$}} & \multicolumn{4}{|c|}{ Utilization $\mathrm{l}^{-1} \mathrm{~h}^{-1}$} \\
\hline & & & & & & $(\mathrm{nm}$ & A.) \\
\hline & & $\begin{array}{l}\text { Glutamic } \\
\text { acid }\end{array}$ & Mix. & $\begin{array}{l}\text { Glutamic } \\
\text { acid }\end{array}$ & Mix. & $\begin{array}{l}\text { Glutamic } \\
\text { acid }\end{array}$ & Mix. \\
\hline \multicolumn{8}{|c|}{ May 1986} \\
\hline 10 & 76.6 & 9.5 & 24.7 & 1036.4 & 2112.2 & 10.88 & 8.56 \\
\hline 35 & 27.6 & 4.0 & 17.4 & 93.2 & 417.9 & 2.34 & 2.40 \\
\hline 100 & 14.9 & 10.1 & 22.8 & 58.8 & 150.7 & 0.58 & 0.66 \\
\hline 300 & 6.4 & 4.7 & 34.4 & 8.9 & 22.0 & 0.19 & 0.06 \\
\hline 500 & 3.9 & 10.3 & 38.5 & 2.8 & 4.2 & 0.03 & 0.01 \\
\hline 700 & 6.9 & 2.9 & 37.7 & 2.9 & 6.1 & 0.10 & 0.02 \\
\hline 850 & 9.9 & 4.0 & 25.9 & 5.4 & 14.9 & 0.13 & 0.06 \\
\hline 905 & 6.8 & 5.9 & 23.5 & 9.7 & 32.2 & 0.16 & 0.14 \\
\hline \multicolumn{8}{|c|}{ October 1986} \\
\hline 10 & 19.5 & 9.7 & 28.7 & 65.5 & 135.7 & 0.67 & 0.47 \\
\hline 35 & 16.9 & 7.1 & 18.9 & 136.3 & 229.5 & 1.92 & 1.21 \\
\hline 100 & 10.2 & 6.9 & 28.4 & 18.8 & 40.6 & 0.27 & 0.14 \\
\hline 300 & 3.9 & 12.8 & 28.2 & 5.5 & 6.3 & 0.04 & 0.02 \\
\hline 500 & 5.4 & 5.6 & 37.0 & 3.8 & 7.5 & 0.07 & 0.02 \\
\hline 700 & 5.0 & 2.0 & 28.0 & 3.0 & 6.9 & 0.15 & 0.02 \\
\hline 850 & 8.8 & 3.4 & 35.2 & 7.0 & 35.0 & 0.21 & 0.10 \\
\hline \multirow[t]{2}{*}{905} & 27.3 & 4.0 & 35.2 & 27.8 & 168.3 & 0.69 & 0.48 \\
\hline & \multicolumn{3}{|c|}{ Mean mole percent $( \pm 1 \mathrm{SD})$} & \multicolumn{4}{|c|}{$\begin{array}{c}\text { Comparison of TFAA utilized with glutamic acio } \\
\text { or mix. as tracer }\end{array}$} \\
\hline May & 6.41 & & $28.1( \pm 7.8)$ & GLU & $0.07+0$. & $\left(r^{2}\right.$ & \\
\hline October & 6.41 & & $30.0( \pm 5.8)$ & GLU & $0.02+0$. & $\left(r^{2}\right.$ & \\
\hline Sum & $6.4 !$ & & $29.0( \pm 6.7)$ & GLU & $-0.02+0$ & $\left(r^{2}\right.$ & \\
\hline
\end{tabular}

per cell was observed in the benthic boundary layer (Table 1). Per cell activity in the BBL approached 60 to $70 \%$ of euphotic zone values in fall, but only 12 to $18 \%$ in either spring study.

Utilization of a single DFAA, glutamic acid, was highly correlated with utilization of a mixture of 3 DFAAs, glutamic acid, aspartic acid and serine, during the May and October 1986 studies (Table 2). Mole percents for both substrates were relatively constant with depth and between the 2 seasons studied. However, estimated TFAA utilization rates using the single DFAA vs the mixture as tracers resulted in a higher $(1.3 \times$ for May $1986,1.5 \times$ for October 1986) estimate for TFAA pool utilization, but the differences were not significant $(p>0.20$ for May; $p>0.05$ for October; Mann-Whitney $U$ test).

The use of glutamic acid in the mixture tends to blunt any differences in results for the 2 tracer choices, since the rate constants for aspartic acid and serine could be as much as 2-fold less than for glutamic acid. Since the absolute TFAA utilization rate is unknown, either tracer employed may actually underestimate or overestimate true rates. Our calculation assumes that all DFAA are utilized at identical rates. We have observed at a nearby location that a minor DFAA (leucine) was utilized at rates similar to the more ubiquitous glutamic acid (Carlucci et al. 1984). In the same study, the apparent rate of utilization for $\beta$-alanine was substantially slower than for leucine, but we subsequently determined that ambient $\beta$-alanine concentrations were overestimated due to co-elution of another major DFAA, taurine. Corrected rates for $\beta$-alanine were similar to those for glutamic acid and leucine. Measured utilization rates, particularly respiration rates, were substantially different only when selected ${ }^{3} \mathrm{H}$-DFAA were added in substantial concentrations $(>2 n M)$ to waters where they were undetectable via HPLC (Carlucci et al. 1986), suggesting stimulation of populations accustomed to oligotrophic conditions.

A summary of euphotic zone chlorophyll a and primary carbon production for the 4 time periods studied here (R. W. Eppley \& E. H. Renger unpubl.) also indicates that apparent seasonal fluctuations in bacterial biomass, TFAA concentration, and utilization discussed previously are related to changes in phytoplankton standing stock and production in the euphotic zone (Table 3). Depth-weighted mean turnover time (hours) was substantially longer in April than at any other time studied. Although TFAA pool size was lower in April 1987, utilization rates were considerably lower 
Table 3. TFAA concentration, estimated utilization, percent respiration and turnover time in central Santa Monica Basin and fraction of primary production represented by TFAA utilization for each of 4 study periods. dwm: depth-weighted mean; mean value of profile parameters weighted for depthinterval integrated

\begin{tabular}{|c|c|c|c|c|}
\hline Parameter (m) & Oct 85 & May 86 & Oct 86 & Apr 87 \\
\hline $\begin{array}{l}\text { Chlorophyll a } \\
\left(m \mathrm{~g} \mathrm{~m}^{-2}\right)\end{array}$ & 19.9 & 62.0 & 13.0 & 24.2 \\
\hline $\begin{array}{l}\text { Primary production } \\
\left(\mathrm{mg} \mathrm{C} \mathrm{m} \mathrm{C}^{-2} \mathrm{~d}^{-}\right)\end{array}$ & 531 & 1254 & 556 & 521 \\
\hline Euphotic zone depth & 48 & 13 & 66 & 51 \\
\hline TFAA $\left(\mathrm{mmol} \mathrm{m}^{-2}\right)$ & 8.6 & 9.4 & 7.0 & 5.3 \\
\hline TFAA-C $\left(\mathrm{mg} \mathrm{m}^{-2}\right)$ & 454.1 & 498.4 & 370.7 & 277.2 \\
\hline $\begin{array}{l}\text { Turnover time }(\mathrm{h}) \\
\text { (dwm) }\end{array}$ & 118 & 134 & 146 & 1033 \\
\hline $\begin{array}{l}\% \text { Respiration } \\
\text { (dwm) }\end{array}$ & 17.7 & 37.4 & 26.2 & 13.8 \\
\hline $\begin{array}{l}\text { TFAA-C utilized } \\
\left(\mathrm{mg} \mathrm{m} \mathrm{m}^{-2} \mathrm{~d}^{-1}\right)\end{array}$ & 92.7 & 88.9 & 60.8 & 6.4 \\
\hline $\begin{array}{l}\text { TFAA-C respired } \\
\left(\mathrm{mg} \mathrm{m} \mathrm{m}^{-2} \mathrm{~d}^{-1}\right) \\
\% \text { Primary production }\end{array}$ & 16.4 & 33.3 & 15.9 & 0.9 \\
\hline $\begin{array}{l}\mathrm{C} \rightarrow \mathrm{CO}_{2} \text { as TFAA } \\
\% \text { Primary production }\end{array}$ & 3.1 & 2.7 & 2.9 & 0.2 \\
\hline$C \rightarrow$ utilized as TFAA & 17.5 & 7.1 & 10.9 & 1.2 \\
\hline
\end{tabular}

throughout the water column compared to May or October of previous years. Depth-weighted mean percent respiration of utilized amino acids was higher in May compared to other times examined, but primary production was also proportionally higher in May so the estimated percent of primary production respired as TFAA was similar to that for both October studies. April was again anomalous. Values reported in Table 3 for all parameters are within the ranges we have presented previously for the same and closely associated marine environments (Carlucci et al. 1984 for euphotic zone, Carlucci et al. 1986 for full column).

Microscopic analyses of short-term (60 h) sediment trap samples from nearby San Pedro Basin in October of 1982 and May of 1983 (Carlucci et al. urpubl.) and benthic microbial activity measurements (Craven et al. 1986) indicate that carbon flux in the environment may be regarded as a mixture of lateral transport from the basin slopes and surrounding shelf areas and fecal pellet transport. We observed very few recognizable phytoplankters in the biogenic fraction of trap splits but numerous fecal pellets and strings. Nelson et al. (1987) report that recognizable biogenic material accounted for only 2 to $3 \%$ of the same trap-collected flux, which was dominated by fecal pellets and amorphous detritus. However, the microscopic studies were performed on samples collected in May of an El Niño event year (1983) and euphotic zone production was lower than normal. Even, so we measured a substantial downward flux of amino acids associated with the detritus (Carlucci et al. unpubl.). Although we cannot invoke the 'phytodetrital' rain described for other areas of the ocean, certainly vertical transport of organic matter is rapid in the region wether composed of phytodetritus or fecal pellets, and given the settling rates described elsewhere for either component, the bloom production probably began to appear in the benthic boundary layer a week or two after the onset of spring bloom. In May of 1986, the central Santa Monica site was visited at what appears to be the beginning of the bloom, since no substantial increases were observed in any mid- or deep water parameters reported. In both October studies, we apparently observed continuing enhanced BBL utilization of bloom-derived DOC, fueled by resuspension or by diffusion out of the sediments. In April 1987, the boundary layer had ceased to display enhanced abundances or activities relative to midwater, but we were too early to sample any euphotic zone bloom. In a previous study at the same site (Carlucci et al. 1986), bloom conditions were already evident in the euphotic zone in March 1982, and benthic boundary layer abundance and/or activity was enhanced as well. In May 1981, such conditions were not observed. Similarly, Lampitt (1985) reported interannual offsets of greater than 1 mo in the occurrence of the spring bloom and subsequent benthic signal in the North Atlantic.

In conclusion, a pronounced benthic enhancement has been observed in TFAA concentration, bacterial abundance and per cell activity, and microheterotrophic DFAA utilization in central Santa Monica Basin in fall compared to spring. Our sampling intervals do not allow any estimate of initial downward transit time for bloom detritus, but we do show that benthic utilization of bloom detritus continues into the fall season in the basin, and that the pronounced benthic activity we measured in October is likely to be much less than that which would be observed if sampling occurred closer to the end of the bloom.

Acknowledgements. Research described here was supported by the Marine Life Research Group of the Scripps Institution of Oceanography, the Department of Energy under Grant DEFG05-85-ER60337, and NSF Grant OCE-8607936. We thank L. Land and M. A. Ogle for manuscript preparation and S. McIntosh for drafting the illustrations, and 3 anonymous reviewers for their useful criticisms of an earlier draft.

\section{LITERATURE CITED}

Billett, D. S. M., Lampitt, R. S., Rice, A. L., Mantoura, R. F. C. (1983). Seasonal sedimentation of phytoplankton to the deep-sea benthos. Nature, Lond. 302: 520-522

Bjornsen, P. K. (1988). Phytoplankton exudation of organic matter why do healthy cells do it? Limnol. Oceanogr. 33 $151-154$ 
Burney, C. M., Davis, P. G., Johnson, K. M., Sieburth, J. McN (1982). Diel relationships of microbial trophic groups and In situ dissolved carbohydrate dynamics in the Caribbean Sea. Mar Biol. 67. 311-322

Carluccl, A. F., Craven, D. B., Henrichs, S. M. (1984). Diel production and microheterotrophic utilization of dissolved free amino acids in waters off southern California. Appl. environ. Microbiol. 48: 165-170

Carlucci, A. F., Craven, D. B., Robertson, K. J., Henrichs, S. M. (1986). Microheterotrophic utilization of dissolved free amino acids in depth profiles of Southern California Borderland basin waters. Oceanologica Acta 9: 89-96

Carlucci, A. F., Shimp, S. L., Craven, D. B. (1987). Bacterial response to labile dissolved organic matter uncreases associated with marine discontinuities. FEMS Microbiol. Ecol. 45: 211-220

Cho, B. C., Azam, F. (1988). Major role of bacteria in biogeochemical fluxes in the ocean's interior Nature, Lond. 332: $441-443$

Codispoti, L. I., Friederich, G. E, Packard, T T, Glover, H. E., Barker, R. T., Elkins, J. W., Ward, B. B., Lipschultz, F., Lostaunau, N. (1986). Extremely high nitrite levels off northern Peru: a signal of instability in the marine denitrification rate. Science 233: 1200-1202

Cole, J. J., Findlay, S., Pace, M. L. (1988). Bacterial production in fresh and saltwater ecosystems: a cross-system overview. Mar. Ecol. Prog. Ser 43: 1-10

Fogg, G. E. (1983). The ecological significance of extracellular products of phytoplankton photosynthesis. Botanica mar. 26: $3-14$

Frost, B. W (1987). Grazing control of phytoplankton stock in the open subarctic Pacific Ocean: a model assessing the role of mesozooplankton, particularly the large calanoid copepods Neocalanus spp. Mar. Ecol. Prog. Ser. 39: 49-68

Henrichs, S. M., Williams, P. M. (1985). Dissolved and particulate amino acids and carbohydrates in sea surface microlayers. Mar. Chem. 17: 141-163

Ittekot, V., Deuser, W. G., Degens, E. T. (1984a). Seasonality in the fluxes of sugars, amino acids, and amino sugars to the deep ocean: Sargasso Sea. Deep Sea Res. 31: 1057-1069

Ittekot, V., Degens, E. T., Honjo, S. (1984b). Seasonality in the fluxes of sugars, amino acids, and amino sugars to the deep ocean: Panama Basin. Deep Sea Res. 31: 1071-1083

Jahnke, R. A., Jackson, G. A. (1987). Role of seafloor organisms in oxygen consumption in the deep North Pacific Ocean. Nature, Lond. 329: 621-623

Jorgensen, N. O. G. (1982). Heterotrophic assimilation and occurrence of dissolved free amino acids in a shallow estuary. Mar. Ecol. Prog. Ser. 8: 145-159

Karl, D. M., Knauer, G. A., Martin, J. H. (1988). Downward flux of particulate organic matter in the ocean: a particle decomposition paradox. Nature, Lond. 332: 438-441

Keller, M. D., Mague, T. H., Badenhausen, M., Glover, H. E. (1982). Seasonal variations in the production and con- sumption of amino acids by coastal microplankton. Estuar coast. Shelf Sci. 15: 301-315

Lampitt, R. S. (1985). Evidence for the seasonal deposition of detritus to the deep-sea floor and its subsequent decomposition. Deep Sea Res. 32: 885-897

Mague, T. H., Friberg, H. E., Hughes, D. H., Morris, I. (1980) Extracellular release of carbon by marine phytoplankton: a physiological approach. Limnol. Oceanogr 25: 262-279

Nelson, J. R., Beers, J. R., Eppley, R. W., Jackson, G. A., McCarthy, J. J., Soutar, A. (1987). A particle flux study in the Santa Monica-San Pedro Basin off Los Angeles: particle flux, primary production and transmissometer survey Cont. Shelf Res. 7: 307-328

Poindexter, J. S. (1981). Oligotrophy: fast and famine existence. In: Alexander, M. (ed.) Advances in microbial ecology, Vol. 5. Plenum Press, New York, p. 63-89

Pomeroy, L. R. (1974). The ocean's food web, a changing paradign. Bioscience 24: 499-504

Rheinheimer, G. (1984). Bacterial ecology of the North and Baltic Seas. Botanica mar. 27: 277-299

Robertson, K. J., Williams, P. M., Bada, J. L. (1987). Acid hydrolysis of dissolved combined amino acids in seawater: a precautionary note. Limnol. Oceanogr. 32: 996-997

Rosso, A. L., Azam, F. (1987). Proteolytic activity in coastal oceanic waters: depth distribution and relationship to bacterial populations. Mar. Ecol. Prog. Ser. 41: 231-240

Smith, K. L., Jr (1987). Food energy supply and demand: a discrepancy between particulate organic carbon flux and sediment community oxygen consumption in the deep ocean. Limnol. Oceanogr. 32: 201-220

Smith, K. L., Jr., Baldwin, R. J. (1984). Seasonal fluctuations in deep-sea sediment community oxygen consumption: central and eastern North Pacific. Nature, Lond. 307: 624-626

Smith, K. L., Jr., Carlucci, A. F., Jahnke, R. A., Craven, D. B. (1987). Organic carbon mineralization in the Santa Catalina Basin: benthic boundary layer metabolism. Deep Sea Res. 34: 185-211

Smith, K. L., Jr., Carlucci, A. F., Williams, P. M., Henrichs, S. M., Baldwin, R. J., Craven, D. B. (1986). Zooplankton and bacterioplankton of an abyssal benthic boundary layer: in situ rates of metabolism. Oceanologica Acta 9: $47-55$

Thomas, J. P. (1971). Release of dissolved organic matter from natural populations of marine phytoplankton. Mar Biol. 11: $311-323$

Urrere, M. A., Knauer, G. A. (1981). Zooplankton fecal pellet fluxes and vertical transport of particulate organic material in the pelagic environment. J. Plankton Res. 3: 369-387

Williams, P. M., Druffel, E. R. M. (1987). Radiocarbon in dissolved organic matter in the central North Pacific Ocean. Nature, Lond. 330: 246-248

Williams, P. M., Druffel, E. R. M. (1988). Dissolved organic matter in the ocean: comments on a controversy. Oceanography $1: 14-17$ 